\title{
The Use of the Way Modeling Method Assisted by Temple Board Media in Learning Indonesian Language
}

\author{
Syarifuddin $^{1}$, Toni Heryadi ${ }^{2}$, Wahyu Bagja Sulfemi ${ }^{3}$ \\ \{toniheryadi7@gmail.com ${ }^{2}$ \} \\ Balai Bahasa Provinsi Jawa Barat, Indonesia ${ }^{1,2}$ \\ Sekolah Tinggi Keguruan Ilmu Pendidikan Muhammadiyah Bogor, Indonesia ${ }^{3}$
}

\begin{abstract}
This study was motivated by the low results of learning Indonesian, which only reached 53.75, where $3(12.50 \%)$ got complete scores. For this reason, it is necessary to improve learning to increase motivation, interest, and learning outcomes of class $\mathrm{V}$ Indonesian language participants at Public Elementary School Kedunghalang 3, Bogor City. The results of the first study obtained an average value of 72.71 . There were tenpeople $(45.45 \%)$ completed. In the second study, the acquisition of the average value increased to 91.14 . There were 21 people or $95.45 \%$ complete and $1(4.55 \%)$ incomplete. The results of teacher observations to see the motivation and interest in learning in the first lesson 11 people $(45.83 \%)$ increased to 22 people $(91.67 \%)$ who are motivated and interested in learning in the second lesson. Learning outcomes using the modeling the way learning method and sticky board media can improve learning activities, learning outcomes, generate interest, motivation, and passion for learning, help students to learn independently, and be responsible.
\end{abstract}

Keywords: Modeling the way, Sticky board media, Indonesian

\section{Introduction}

Indonesian is one of the scientific fields taught from elementary to tertiary level. General competence that students in elementary schools must have in learning Indonesian can communicate in writing and orally correctly and adequately [1]. Meanwhile, the specific objective is for students to communicate well, including speaking, writing, reading, listening skills, and students can work and imagine doing various literary works well [2]. Furthermore, Mulyati argued that there are two categories in understanding language skills, namely productive and receptive aspects. In the productive aspect, namely the expenditure or production of various forms of written and spoken language, such as learning to write and speak. The receptive aspect is the absorption or acceptance of a student in learning activities such as reading and listening [3].

The results of Indonesian language learning conducted on 5th-grade students of Kedunghalang 3 Elementary School, Bogor City, from the predetermined minimum completeness criteria, it was only able to reach an average value of 53.75, which is still far from the predetermined value. Likewise, the observation results of students' motivation in answering questions showed that only $20.83 \%$ or 5 of the 24 students could answer questions from the 
teacher. These results indicate problems in learning activities in terms of motivation, interest, and student learning outcomes. If sulking on the model, methods and media users needs to be reviewed so that student learning becomes better and the results can reach and even exceed the set value.

The low results of Indonesian following studies or research from Nikmah from Muria Kudus University related to the same problem, namely the skill to write an invitation letter in Class V SD Tuwang 1 Demak, indicates a problem related to the activeness of students and writing skills in learning which affects the lack of understanding material [4]. Likewise, research conducted by Isthifa and Fitriani revealed that currently, the writing technique skills and writing skills of students were not satisfactory and had not reached the maximum target [5].

From this research, there is the same problem, where they do not convey about the interest and motivation of students in learning and only use the Modeling the Way learning model, not using temple board media. For this reason, learning improvements are made using the Modeling the Way model with a combination of sticky board media. This method's use is expected that: 1 can generate interest, motivation, and enthusiasm for student learning. 2) Can guarantee the development of students during the teaching and learning process. 3) develop students' creativity, expression, personality, learning motivation, and 4) students to become independent in learning and take responsibility. Likewise, sticky board media can attract students' attention, and students can remember and inform learning, become a container for creativity in group work, and give birth to aesthetic and beauty values because of the diverse and harmonious arrangements. The main result of this learning is creating fun learning. So that in this lesson, the teacher's task is only to act as a motivator, mediator, and facilitator.

\section{Methods}

The method used in this research is Classroom Action Research, which means that action research is carried out in class [6]. Sukiyaki and Fauzi stated that this study's objectives were 1) Improving and enhancing learning 2) Improving the quality of education. 3) Fostering an academic culture in the school environment [7], [8]. This study's subjects were 24 students consisting of 13 boys and 11 girls from Kedunghalang 3 Elementary School, Bogor City. This school is located on Jl. Foreman Naiman RT 05/02 PasirJambu, Sukaraja District, Bogor City, West Java Province with NPSN 20220500.

Analyze data by reviewing, grouping, systematizing, interpreting, and verifying data so that a phenomenon has social, academic, and scientific value. Furthermore, the data collected in each activity were analyzed descriptively using the percentage technique to see developments that occurred in learning activities in Indonesian subjects. In carrying out this research, two cycles of improvement are needed for Indonesian subjects [9]. In the learning improvement process, the researcher carried out three stages: planning, implementing, observing, and reflecting [10].

The data were collected by analyzing the written test results in each cycle in the following way: 1) In the pre-cycle questions, there were five multiple-choice questions and fivequestions with predetermined assessment points; 2) In cycle one, there are five multiple-choice questions and tenentries with predetermined assessment points; 3 ) in Cycle 2 with five multiple-choice questions and fiveentries with predetermined score points. The following assessments are carried out for the observation sheet with the discussions with class teachers about the advantages and disadvantages of implementing learning [11], [12]. 
The formula for calculating the student learning evaluation results for each cycle is the number of correct answers divided by the total score divided by 100 . Next, determine the value range $(\mathrm{R})$ for each cycle with the formula $\mathrm{R}=$ the largest value minus the smallest value. The next step is to determine the number of interval classes $(B)$ with the formula: $B=1+3,3 \log n$, ( $\mathrm{n}$ is many data). The final step is to determine the interval class's length (p) using the formula: $\mathrm{P}=$ Value Range divided by Many Classes [13], [14], [15].

\section{Results and Discussion}

The learning improvement process starts from the Pre-Cycle, then continues with learning twice, namely Cycle 1, which is an improvement from the initial learning, then Cycle 2 is an improvement from learning in Cycle 1. The time allocation for each study is 70 minutes or 2 hours learn). In the learning process activities from Pre-Cycle to Cycle 2, researchers are assisted by the teacher to observe the strengths and weaknesses of learning.

In pre-cycle learning, the lecture method is used with blackboard media and Indonesian language learning books. Learning activities are divided into three stages, namely first, planning with activities, namely: a) making learning plans, b) looking for indicators and objectives in learning, c) making and determining learning steps, d) determining material e) determining and making tools and learning media, f) preparing and making worksheets for students, and $\mathrm{g}$ ) making and compiling learning evaluations. The second stage is the implementation stage. At this stage, it is divided into preliminary, core, and closing activities. Preliminary activities are carried out in the following stages: a) the teacher greets students and invites students to pray, b) Performs student attendance, c) Motivates by clapping the focus and sings the song "Halo-Halo Bandung", d) conveys objectives in learning, and e) do a question and answer. Furthermore, in the core activities as addressed by Sulfemi, the following actions were carried out: a) the teacher explained the Indonesian learning material to write an official invitation letter, b) students were asked to pay attention, and c) the teacher asked whether the students understood the material. Finally, the activity is closed by carrying out the following activities: a) students are welcome to ask questions that are not yet known, b) teachers and students conclude the material, c) students are ordered to work on worksheets, d) the teacher checks the answers of each student, e) the teacher provides feedback, f) the teacher provides motivation, reinforces the material and closes the lesson [16].

Based on observations during the Pre-Cycle using the lecture method, the total score was 1290, and the mean was 53.75. 3 students completed (12.50\%) while 21 students $(87.50 \%)$ did not complete. The highest score is 80 , and the lowest score is 20 . These scores are far from the minimum completeness criteria set.

Based on data, the interval's value, namely the class distance of 60 , the class interval of 5.29 is rounded to a value of 5 , and the interval class length (p) 12 . From these data, the value range of 20 - 32 consists of 3 people (12.50) range of values 33 - 45 there were fivepeople (20.83), the value range 46 - 58 contained sixpeople (25.00), the value range 59 - 68 contained sevenpeople (29.17) and the value range 69 - 81 contained threepeople $(12,50)$. The following is a graph of the frequency of pre-cycle learning outcomes. Following are the results of the precycle interval values in the graph in Figure 1 below. 


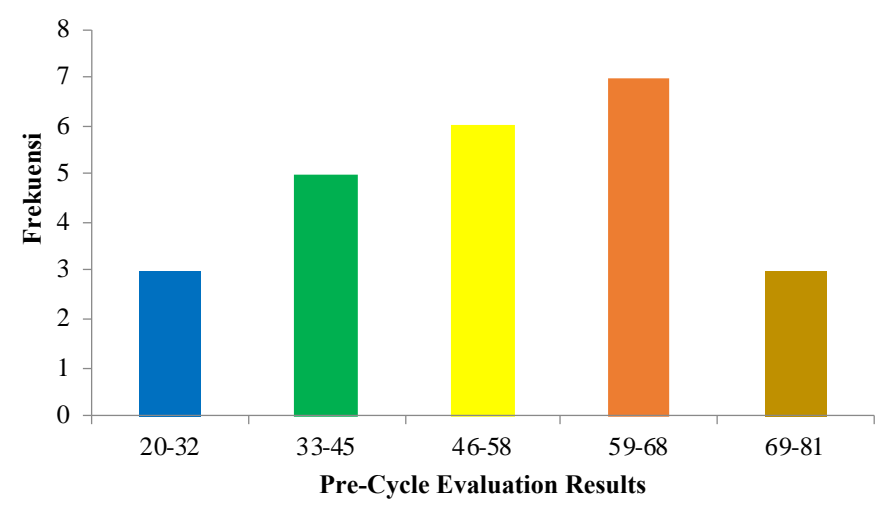

Fig. 1. Pre-Cycle Learning Outcomes Distribution Frequency

From Figure 1, it can be seen that most of the students who are in the 59-68 value range are 7 students or $29.17 \%$. Thus, Pre-Cycle learning is dominated by students who are under the maximum completeness criteria.

To see motivation and interest in learning, observations are made by the teacher in a way that can answer and can't. The results of teacher observations, there were fivestudents or $20.83 \%$, who were able to answer the teacher's questions well. Meanwhile, 19 students or $79.17 \%$, were not able to answer questions raised by the teacher.

After knowing the pre-cycle results did not reach the specified minimum completeness, it was continued with improving learning or cycle oneactivities using the method of modeling the way. Preliminary planning and implementation are the same as activities during the pre-cycle, which differentiate between core activities. In this activity, as conveyed by Rakasiwi, the following activities were carried out: 1) the teacher explained the material, students were asked to observe examples of official letters in the textbook. 2) Students respond to examples of official letters they observe. 3) Teachers and students carry out question and answer activities accompanied by examples, sections, and characteristics of official letters. 4) Students are divided into 5 groups then discuss examples of formal invitation letters from textbooks. 5) Students discuss with their groups to determine the parts of the letters by filling in student worksheets in the textbook. 6) Each group exchanges the results of the discussion and gives each other an assessment with teacher guidance. 7) Students do individual assignments on the worksheet, and 8) The teacher checks each student's answers [17].

At the end of the learning activity, the following actions were carried out: 1) The teacher and students reflected on the teaching and learning activities by asking the question: "Do you understand this material?". and "Would you like to write a letter after studying this?" 2) conclude the material between the teacher and students about learning outcomes. 3) students and teachers say hamdalah and prayers.

Learning cycle 1 obtained an overall value of 1.745 and a mean of 72.71 . Tenstudents completed or $41.67 \%$, while 14 students or $58.33 \%$ students had not finished. The highest score is 100 , and the lowest is 50 . The interval data can be calculated with a class value range of 50, the multi-class interval is 5.29 rounded to the number 5 , and the class length interval is 10 . From data, there are fourstudents in 50-59 value range or 16.67 percent, the range of values from 60 to 69 there were 7 people or 29.17 percent, in the range of values 70 to 79 there were 7 people or 29.17 percent, in the range 80 - 89 there were 3 people or 29.17 percent, and in the range of 90 up to 100 , there are 3 people or 12.50 percent-the frequency of the learning cycle. The 
results of learning cycle 1 are presented in the graph in Figure 2 below to see the results of the interval data.

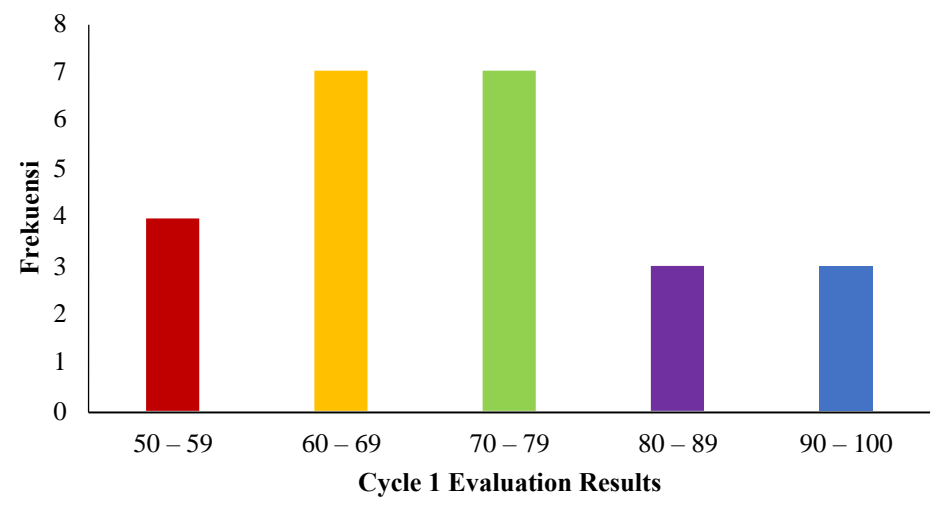

Fig. 2. Frequency Distribution of Learning Cycle Results 1

The graph in Figure 2 that learning cycle onehas increased with the highest number of students in the range of 60 - 69 and the range of $70-79$, namely there are sevenstudents or $29.17 \%$. However, these results have not improved overall student learning outcomes that are still below the minimum completeness criteria.

To see motivation and interest in learning, observations are made by the teacher in a way that can answer and can't. The teacher's observations during learning in cycle 1 were 11 people or $45.83 \%$, and 13 students, or $54.17 \%$, were still unable to be motivated in learning activities. After learning in cycle 1 the average value was still below the set. The researchers made improvements in cycle 2 by still using the method of modeling the way but adding sticky board media during learning. The pasting board media is a board with A3 size.

In the implementation of learning cycle 2 , it is almost the same as cycle 1 , which distinguishes only core activities. The following are the core learning activities of cycle 2:1) Delivery of material by the teacher using instructional videos, students are asked to pay attention, 2) the teacher instructs students to sit in groups and follow a game on how to compile parts of an official invitation letter, 3) students grouped into 5 and given an assessment sheet, 4) the teacher will determine the order of the groups that will advance to compete in compiling parts of the official invitation letter through a lottery, 5) students who are members of the two groups compete to compile parts of the official invitation letter on the sticky media impraboard within 3 minutes in front of the class, 6) each group gives mutual appreciation and response verbally to other groups who have compiled an official invitation letter and gave an assessment on the assessment sheet provided, 7) after completion all groups move to the front of the class, each group writes a formal invitation letter on recycled paper repetitions that have been brought from home based on the description of the letter according to the official invitation letter format, 8) each group evaluates the work results with guidance from the visual media displayed by the teacher, 9) students do individual assignments, and 10) the teacher checks students' answers.

The results of Cycle 2 learning obtained a total value of 2195, an average value of 91.46 . This result exceeds the minimum completeness criteria, namely 75.00 . There were 23 or $95.83 \%$ who got complete scores, and there was onestudent or $4.17 \%$ who did not complete. A score of 100 is the highest score, and 70 is the lowest score. 
The interval calculation from the data above shows that the class range is 30 , many class intervals are 5.29 or rounded to a value of 5 , and the class interval or (p) is 6 . Based on this, it can be seen that the participants who are in the 70- 75 there is oneperson (4.17\%), in the range 76 - 81 there are fourpeople (16.67\%), in the range of values $82-87$ there is oneperson $(4.17 \%)$, in the range of values 88 - 93 there are sevenpeople $(29.17 \%)$, and values $94-100$ there are 11 people $(45.83 \%$.) The results of the intervals in learning in cycle twocan be seen in Figure 3 below.

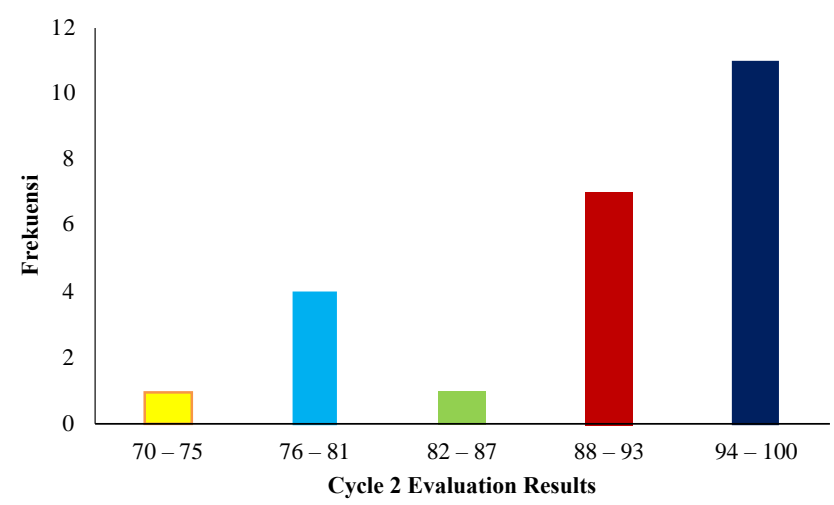

Fig. 3. Frequency of Distribution of Learning Outcomes in Cycle 2

Based on Figure 3, the highest values are $94-100$, which reaches $45.83 \%$. Thus, in cycle 2 , learning was dominated by the achievement of the minimum completeness criteria. To see motivation and interest in learning, observations are made by the teacher in a way that can answer and can't. The results of teacher activities observed during teaching and learning activities in Cycle 2 were 22 students who had the rightmotivation during the learning activities of Cycle 2 or $91.67 \%$. Meanwhile, as many as twostudents, or $8.33 \%$, were still unable to be motivated in learning activities.

Based on the overall data during the learning process, a summary of each cycle's learning outcomes can be made. The following are the results of learning Indonesian for each cycle, which is presented in table 1 below.

Table 1. Indonesian Language Learning Outcomes

\begin{tabular}{llllllll}
\hline \multirow{2}{*}{ No } & \multirow{2}{*}{ Score } & \multicolumn{2}{c}{ Pre-Cycle } & Cycle 1 & \multicolumn{3}{c}{ Cycle 2 } \\
\cline { 2 - 7 } & & Amount & \% & Amount & \% & Amount & \% \\
\hline 1 & Complete & 3 & 12.50 & 10 & 41.67 & 23 & 95.83 \\
2 & Not Complete & 21 & 87.50 & 14 & 58.3 & 1 & 4.17 \\
3 & Average & 53.75 & & 72.71 & & 91.46 & \\
\hline
\end{tabular}

Based on Table 1, learning Indonesian from pre-cycle to cycle 2 continues to increase. The following is a summary of each cycle's learning outcomes, which is presented in the graph in Figure 4. 


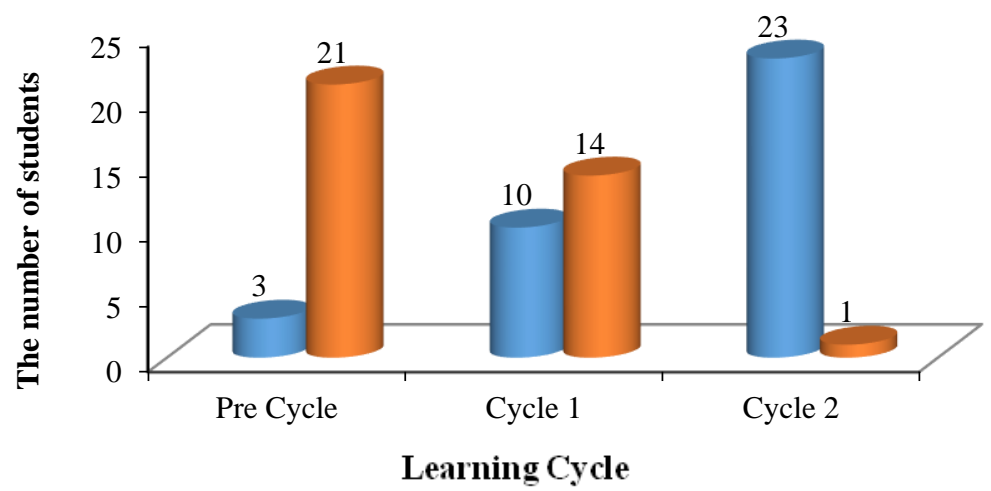

Fig. 4. Students' Completeness in Each Cycle

The data in graph fourabove shows an increase in student learning outcomes in each cycle. Whereas for a summary of the results of observations to see motivation and interest in learning, observations are made by the teacher in a way that can answer and cannot answer, the table is presented in table 2 below.

Table 2. Percentage of Successful Observations for Each Cycle.

\begin{tabular}{llllllll}
\hline \multirow{2}{*}{ No. } & \multirow{2}{*}{ Criteria } & \multicolumn{2}{c}{ Pre-Cycle } & \multicolumn{3}{c}{ Cycle 1 } & \multicolumn{3}{c}{ Cycle 2 } \\
\cline { 2 - 7 } & & Amount & $\%$ & Amount & Amount & \% & Amount \\
\hline 1 & Can Answer & 5 & 20.83 & 11 & 45.83 & 22 & 91.67 \\
2 & Cannot Answer & 19 & 79.17 & 13 & 54.17 & 2 & 8.33 \\
\hline
\end{tabular}

Based on the results of Table 2, a summary graph of teacher observations was made in seeing student motivation and interest. Following are the results of student motivation and interest in learning which are shown in the graph in Figure 5 below.

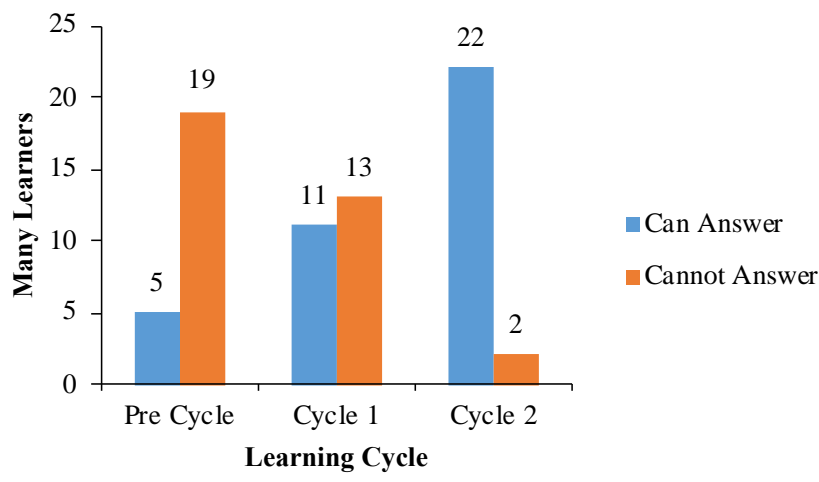

Fig. 5. Results of Observation of Indonesian Language Learning

By looking at table 2 and Figure 5, the comparison of the acquisition of motivation and interest in learning through teacher questions and answers in pre-cycle, cycle I, and cycle II 
continues to increase. This shows that students' understanding of learning has also increased. This study's results are consistent with research from Anegawati and Riananda's research that the method of modeling the way can provide several things, namely 1) Increasing students' understanding and knowledge, 2) arousing interest, motivation, and enthusiasm. students in learning, 3) can guarantee the development of students in learning, 4) express students' expression, creativity, and personality, 5) stimulate students to be more active in studying, 6) help students in learning alone or independently, and 7) can guide students as well to be responsible. [18], [19].

Likewise, the use of sticky board media provides several things, namely 1) It can attract students' attention, especially if it is placed in a strategic place, 2) Can be used to remember and inform student behavior, 3) Students become creative, 4) the emergence of aesthetic values and beauty due to diverse and harmonious arrangements, deep, and, 5) the creation of a sense of responsibility and love for the work and appreciation for the work of his friends [20], [21].

However, students whose learning outcomes do not reach the minimum completeness criteria because of weaknesses in experiments and data collection. These results prove that modeling how media on the sticky board has provided good enough learning outcomes and motivation for students. Therefore, learning reaches cycle 2 because the learning has been successful, with an increase in the student's average score that exceeds the set score.

\section{Conclusion}

This discussion can be drawn the following conclusions: First, the use of method modeling media and sticky boards can improve learning outcomes in Indonesian subjects. This can be seen from the learning outcomes in the second cycle, reaching an average of 91.46. Second, the increase in student interest and motivation can be seen from teacher observations that in cycle II, there were 22 people, or $91.67 \%$, who were able to answer questions given by the teacher in question and answer. Third, the escape of expression, creativity, the formation of student personality, which is responsible for helping students to learn independently, and making the learning atmosphere fun so that students and educators enjoy the learning process.

Based on these conclusions, several things must be done, namely: 1) teachers should improve and analyze the quality of learning to improve, generate interest, motivation, and learning outcomes, 2) Teachers get used to it continuously, periodically, programmatically, and continue to improve the quality of learning, especially Indonesian language lessons, and 3) There is a need for further research, with other subjects and themes.

\section{Acknowledgment}

This study would not have been carried out without several parties forming it. Therefore, the authors would like to thank the observers from Bismas 2020, LPPM STKIP Muhammadiyah Bogor, Head of the West Java Language Center, Principal of SDN Kedunghalang 3 Bogor City Mrs. EtiKurniati, S. Pd. 


\section{References}

[1] W. B. Sulfemi and H. Minati, "Meningkatkan Hasil Belajar Peserta Didik Kelas 3 Sd Menggunakan Model Picture and Picture Dan Media Gambar Seri,” J. Pendidik. Sekol. Dasar, vol. 4, no. 2, p. 228 , 2018, doi: 10.30870/jpsd.v4i2.3857.

[2] D. Anggraini, "Pengembangan Alat Permainan Edukatif Dengan Barang Bekas Untuk Mengembangkan Bahasa Anak Usia Dini Di Ra Al-Hidayah Kecamatan Kasui Kabupaten Waykanan," Universitas Negeri Raden Intan, 2018.

[3] M. Mulyati, Terampil Berbahasa Indonesia untuk Perguruan Tinggi, Cetakan Ke. Jakarta: Penerbit Kencana, 2017.

[4] E. Z. Nikmah, "Peningkatan Keterampilan menulis Surat Undangan Melalui Model quantun Writing Berbantuan Media Puzzle Kelas VD SD Tuwang 1 Demak," UNIVERSITAS MURIA KUDUS, 2017.

[5] I. Kemal and F. Fitriani, "Kemampuan Menulisi Surat Undangan Siswa Kelas Vd Min Mesjidi Rayai Banda Aceh," J. Tunas Bangsa, vol. 1, no. 1, pp. 15-29, 2014, [Online]. Available: https://ejournal.bbg.ac.id/tunasbangsa/article/view/592.

[6] W. B. Sulfemi and N. Yuliani, "Model Pembelajaran Contextual Teaching And Learning (CTL) Berbantu Media Miniatur Lingkungan Untuk Meningkatkan Hasil Belajar IPS," Edunomic J. Pendidik. Ekon., vol. 7, no. 2, p. 73, 2019, doi: 10.33603/ejpe.v7i2.1970.

[7] [Sukayati [Sukayati, Penelitian Tindakan Kelas di SD, vol. 1, no. 1. Yogyakarta: Pusat Pengembangan dan PemberdayaanPendidik dan Tenaga KependidikanMatematika, 2019.

[8] W. B. Sulfemi and D. Yuliana, "Penerapan Model Pembelajaran Discovery Learning Meningkatkan Motivasi dan Hasil Belajar Pendidikan Kewarganegaraan,” PEDADIDAKTIKA J. Ilm. Pendidik. Guru Sekol. Dasar, vol. 5, no. 1, pp. 23-31, 2018, [Online]. Available: https://jurnal.stkippgritulungagung.ac.id/index.php/rontal/article/view/1021.

[9] A. Irmawati, "Keefektifan Model Experiential Learning Dalam Pembelajaran Menulis Puisi Naratif Siswa Kelas VIII SMP Negeri 2 Dua Pitue Kabupaten Sidrap," Totobuang, vol. 7, no. 2, pp. 139 155, 2019, doi: https://doi.org/10.26499/ttbng.v7i1.113.

[10] W. B. Sulfemi and Y. Kamalia, "Jigsaw Cooperative Learning Model Using Audiovisual Media To Improve Learning Outcomes,” J. Pendidik. Sekol. Dasar, vol. 6, no. 1, pp. 30-42, 2020, doi: http://dx.doi.org/10.30870/jpsd.v6i1.4919.g5063.

[11] I. A. . Wardani, "PenelitianTindakani Kelas," in Penelitian tindakan kelas, Jakarta: Universitas Terbuka, 2019, pp. 1-86.

[12] A. Suharsimi, "Penelitian Tindak Kelas (PTK)," in LPMP Yogyakarta, Yogyakarta: Pustaka, 2007.

[13] P. H. Pebriana, "Application of Hypnoteaching Method to Improve Children's Poetry Writing Ability in Class Iii Sdn 030 Bagan Jaya Students," J. Basicedu, vol. 2, no. 1, pp. 148-153, 2018, [Online]. Available: https://media.neliti.com/media/publications/278070-penerapan-metodehypnoteaching-untuk-men-048c2c07.pdf.

[14] W. B. Sulfemi and N. Mayasari, "The Use of Audio Visual Media in Value Clarification Technique to Improve Student Learning Outcomes in Social Studies,” J. Pendidik., vol. 20, no. 1, pp. 53-68, 2019, doi: https://doi.org/10.33830/jp.v20i1.235.2019.

[15] E. Prihatiningsih and E. W. Setyanigtyas, "Pengaruh Penerapan Model Pembelajaran Picture and Picture Dan Model Make a Match Terhadap Hasil Belajar Siswa,” J. Pendidik. Sekol. Dasar, vol. 4, no. 1, p. 1, 2018, doi: 10.30870/jpsd.v4i1.1441.

[16] W. B. Sulfemi, "Model Pembelajaran Kooperatif Mind Mapping Berbantu Audio Visual Dalam Meningkatkan Minat, Motivasi Dan Hasil Belajar Ips,” J. PIPSI (Jurnal Pendidik. IPS Indones., vol. 4, no. 1, p. 13, 2019, doi: 10.26737/jpipsi.v4i1.1204.

[17] A. Rakasiwi, "Pengaruh Model Pembelajaran Modelling the Way Terhadap Pelaksanaan Ibadah Sehari-Hari," Atthulab Islam. Relig. Teach. Learn. J., vol. 3, no. 1, pp. 82-97, 2018, doi: 10.15575/ath.v3i1.4201.

[18] E. Anegawati, "Penerapan Strategi Pembelajaran ModellingThei Way Untuk Meningkatkan Hasil Belajar Pendidikan Agama Islam (PAI) Siswa Kelas IV SD Negeri 010 Banjar Panjang Kecamatan 
Kerumutan,” PRYMARI J. Pendidik. Guru Sekol. Dasar, vol. 5, no. 3, pp. 618-633, 2016, doi: DOI: http://dx.doi.org/10.33578/jpfkip.v5i3.3947.

[19] D. M. Riananda, E. E. Subekti, and M. A. KHB, "Implementasi Metode Modelling The Way dengan Permainan Mathchess untuk Meningkatkan Keterampilan Perkalian,” J. Ilm. Sekol. Dasar, vol. 3, no. 4, p. 403, 2019, doi: 10.23887/jisd.v3i4.21766.

[20] A. N. Wulandari and M. Mawardi, "Pengembangan Media Papan Tempel Bangun Datar Berbasis Pemecahan Masalah Matematika Siswa Kelas 4 SD, ” J. Chem. Inf. Model., vol. 53, no. 9, pp. 1689_ 1699, 2013, [Online]. Available: https://pigur.ejournal.unri.ac.id/index.php/pigur/article/download/5984/5506.

[21] M. Sageileppak, "Upaya Meningkatkan Keaktifan Belajar Siswa Menggunakan Media Papan Tempel Gambar Mata Pelajaran PKn,” J. Basic Educ., vol. 5, no. 21, pp. 24-35, 2016, [Online]. Available: http://journal.student.uny.ac.id/ojs/index.php/pgsd/article/view/2601. 